\title{
Performance evaluation of a flatbed maize dryer with a biomass heat source
}

\author{
J.O. Akowuah ${ }^{1 *}$ (D) H.A. Boateng ${ }^{1}$, G. Obeng-Akrofi ${ }^{2}$ and D.E. Maier ${ }^{2}$ \\ Received 21 October 2021, Revised 15 November 2021, Accepted 20 December 2021, Published online 31 December 2021
}

\section{A B S T R A C T}

The technical performance of a 3-tonne capacity flatbed grain dryer was assessed based on its drying rate and drying efficiency. In addition, the quality of maize grains dried in the drying system was investigated through stress-crack analysis and germination test. Maize grains at an initial moisture content of $18.4 \% \pm 0.1 \%(\mathrm{wb})$ were dried to a safe moisture content of $13.3 \% \pm 0.2 \%(\mathrm{wb})$ in 5 hours, resulting in a drying rate of $1.02 \% / \mathrm{h}$ at a drying efficiency of $67.35 \%$. The average temperature observed in the plenum $\left(55.8^{\circ} \mathrm{C} \pm 1.5^{\circ} \mathrm{C}\right)$ was about twice higher than the ambient temperature during the drying period. The use of the flatbed dryer did not have any adverse effect on the viability of grains dried with a stresscrack index of 75 and percentage germination of $90 \%$. This study demonstrated the viability of using the flatbed biomass-assisted dryer for drying maize and can reduce post-harvest losses of maize at the smallholder level.

Keywords: Flatbed biomass dryer, Drying rate, Drying efficiency, Stress crack index, Germination

${ }^{I}$ Department of Agricultural and Biosystems Engineering, Kwame Nkrumah University of Science and Technology, Kumasi, Ghana

${ }^{2}$ Department of Agricultural and Biosystems Engineering, Iowa State University, Ames, Ia USA

*Corresponding author's email: akowuahjoe@yahoo.co.uk (J.O. Akowuah)

Cite this article as: Akowuah, J.O., Boateng, H.A., Obeng-Akrofi, G. and Maier, D.E. 2021. Performance evaluation of a flatbed maize dryer with a biomass heat source. Int. J. Agril. Res. Innov. Tech. 11(2): 37-41. https://doi.org/10.3329/ijarit.v11i2.57253

\section{Introduction}

Maize is a staple crop in Ghana for both humans and livestock. The economic importance of maize and its role in ensuring food security in Ghana cannot be over-emphasized. The per capita consumption (kg/annum) of maize in Ghana is estimated at $45 \mathrm{~kg}$ and estimated national consumption of 1,273,874 Mt (Angelucci, 2019). Despite the increase in the production of maize, post-harvest losses (PHLs) during storage remain a significant challenge for many smallholder farmers in developing countries (Abass et al., 2014). At harvest moisture contents between $20 \%$ to $30 \%$, food grains need to be conditioned to $12 \%$ to $14 \%$ moisture content to ensure safe storage for a long period, particularly in tropical regions like Ghana.

In Ghana, maize drying is mainly done using the open-sun drying method or mechanized dryers, with limited solar dryers. Open-sun drying is the oldest, most inexpensive and widely used option by the majority of the smallholder farmers who grow maize. This method has major setbacks involving exposure of grains during drying to unfavourable environmental conditions making the grains susceptible to pest infestation and fungal contamination. The process is also labour intensive as it requires large area for spreading and the need for stirring, which is timeconsuming and unreliable, leading to nonuniform drying in most cases. This facilitates the rapid deterioration of the grains due to mould and mycotoxins contamination, leading to food loss (Delouche et al., 2016).

Recent research on dryer technologies for smallholder grain farmers in sub-Sahara Africa focuses on the development of small capacity drying systems that can meet their drying needs (Obeng-Akrofi et al., 2021; Akowuah et al., 2018; Kumar and Kalita, 2017) to minimize degradation of quality attributes of the product during drying. Different prototypes of low capacity dryers such the AflaStop (M50o EasyDry), the STR Column dryer, the Solar Bubble Dryer ${ }^{\mathrm{TM}}$ (GrainPro, Zambales, Philippines) with drying capacities of 0.5 to 1 tonne have been developed and recently introduced to smallholder farmers in sub-Sahara Africa. Successful performance assessment of such low-capacity drying units, as undertaken by authors (Owusu-Sekyere et al., 2021; ObengAkrofi et al., 2021; Armah et al., 2021), is needed to drive their scale-up, commercialization, and adoption by smallholder farmers. This study 
sought to assess the performance of a locally developed 3-tonne capacity flatbed maize dryer with a biomass burner for drying maize in Ghana. Specifically, the objectives of the study were to-

(1) determine the exergetic performance of the dryer; (2) assess the effect of the drying air temperature on grain damage and germination.

\section{Materials and Methods}

\section{Dryer Description}

The biomass fired flatbed dryer was designed at the Agricultural Engineering Department of the Kwame Nkrumah University of Science and Technology Kumasi. It consists of a drying platform and a biomass furnace. The drying chamber (B) has a plenum enclosed with burnt clay bricks to prevent heat loss, and has a perforated metal sheet that holds the grain to be dried. The dryer is $0.3 \mathrm{~m}$ high with a length and width of $3.7 \mathrm{~m}$ and $2.4 \mathrm{~m}$, respectively. The outlet of the dryer is connected to a screw auger (C) to convey dried maize grains for easy bagging into storage sacks. Hot air from the heat exchanger enclosed with bricks (A) is forced through the drying bed by an induced draft fan connected to the furnace and plenum as illustrated in the Fig. 2.

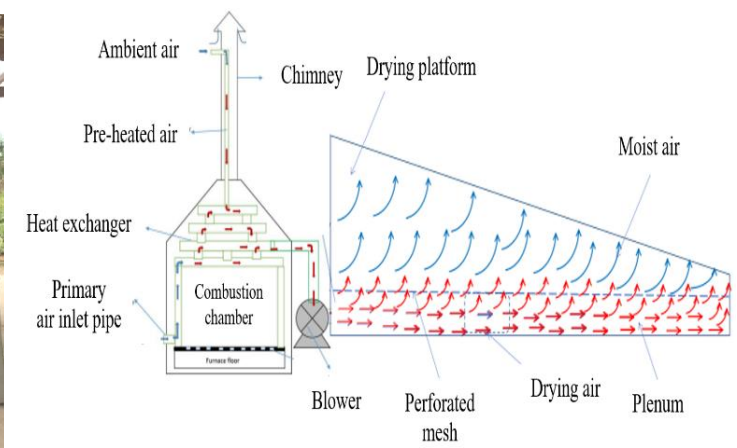

Fig. 2. A schematic view of hot air flow from the heat exchanger through the plenum.

extraction rate, drying efficiency and specific energy consumption.

\section{Burner efficiency (BE)} the drying experiment. The MC of maize grains during the drying experiment was monitored at 30 minutes interval with a pre-calibrated John Deere moisture meter manufactured by AgraTronix $^{\mathrm{TM}} \quad$ (Moisture Check Plus ${ }^{\mathrm{TM}}$ ), (SWo8120, Moline, IL, USA). Maize grains were sampled at different positions after each stirring and mixed thoroughly before the MC reading was taken and recorded. Three measurements were taken at each period and the mean value was calculated for analysis. Similarly, the temperature distribution in the dryer was monitored using a Kestrel wireless temperature and humidity data loggers (DROP D2, Boothwyn, PA, USA) which were placed at $3 \mathrm{ft}(0.9 \mathrm{~m}), 6 \mathrm{ft}(1.8 \mathrm{~m})$, and $9 \mathrm{ft}$ $(2.7 \mathrm{~m})$ along the length of the dryer. The surface temperature of drying grains on the drying platform was also monitored using an infrared thermometer (Lasergrip 1022, Etekcity Corporation, Anaheim, CA, USA). The airflow rate during the experiment was measured with the aid of a thermo-anemometer (Extech, Melrose, MA, USA) at the suction end of the blower.

\section{Dryer Performance}

The dryer performance was assessed in terms of its burner efficiency, drying rate, moisture
The burner efficiency was calculated using Equation 1

$B E=\frac{\text { Maĩ } \times(\text { CPair x (Tair }- \text { Tamb) }}{\text { Mbe } \times H V} \times 100$

Where,

$M_{\text {air }}=$ mass flow of air $(\mathrm{kg} / \mathrm{hr}), T_{\text {air }}=$ temperature of hot air exiting the heat exchanger $\left({ }^{\circ} \mathrm{C}\right), T_{a m b}=$ temperature of the ambient condition $\left({ }^{\circ} \mathrm{C}\right), C P_{\text {air }}$ $=$ specific heat capacity of air $\left(\mathrm{kJ} / \mathrm{kg} .{ }^{\circ} \mathrm{C}\right), H V=$ heat value of corncobs $(\mathrm{kJ} / \mathrm{kg})$ and $M_{b c}=$ feed rate of biomass $(\mathrm{kg} / \mathrm{hr})$.

\section{Drying Rate, $D_{R}$}

The drying rate was calculated using Equation 2.

$D_{R}=\frac{M i-M f}{t}$

Where,

$\mathrm{D}_{\mathrm{R}}=$ is the drying rate in $\% / \mathrm{hr}, \mathrm{M}_{\mathrm{i}}=$ initial moisture content (\% w.b.), $\mathrm{M}_{\mathrm{f}}=$ final moisture content (\% w.b.) and $\mathrm{t}=$ drying time (h). 


\section{Moisture Extraction Rate (MER)}

Moisture extraction rate was determined using Equation 3.

$M_{E R}=\left(W_{i} \times\left(\frac{M_{i}-M_{f}}{100-M_{f}}\right)\right) / t$

Where,

$\mathrm{M}_{\mathrm{ER}}=$ moisture extraction rate $(\mathrm{kg} / \mathrm{hr}), \mathrm{W}_{\mathrm{i}}=$ initial mass of grain dried $(\mathrm{kg}), \mathrm{M}_{\mathrm{i}}=$ initial moisture content (\% w.b.) and $\mathrm{M}_{\mathrm{f}}=$ final moisture content (\% w.b.) and $\mathrm{t}=$ drying time (h).

\section{Drying Efficiency, $\eta$}

The drying efficiency, which gives the ratio of the energy used to evaporate moisture from the product to the energy provided by the drying air, was determined using Equation 4.

$\eta=\frac{M_{E R} L_{W}}{M_{\text {air }} C p_{\text {air }} \Delta T} \times 100$

Where,

$\eta=$ drying efficiency (\%), $\mathrm{M}_{\mathrm{ER}}=$ rate of moisture evaporation $(\mathrm{kg} / \mathrm{hr}), \mathrm{L}_{\mathrm{v}}=$ latent heat of vaporization of water $(\mathrm{kJ} / \mathrm{kg}), \mathrm{M}_{\text {air }}=$ mass flow rate of air $(\mathrm{kg} / \mathrm{hr}), \mathrm{Cp}_{\mathrm{air}}=$ specific heat capacity of air $\left(\mathrm{kJ} / \mathrm{kg}{ }^{\circ} \mathrm{C}\right)$ and $\Delta \mathrm{T}=$ change in temperature between the ambient and drying air $\left({ }^{\circ} \mathrm{C}\right)$.

\section{Specific Energy Consumption (SEC)}

The specific total energy consumption which is the total energy used per kilogram of moisture evaporated (MJoules per kilogram of moisture removed) was determined using Equation 5.

Specific Energy Consumption $=\frac{M_{\text {Biomass }} \times H_{\text {Biomass }}}{M_{w}}$

Where,

$\mathrm{M}_{\text {Biomass }}=$ mass of biomass combusted during drying $(\mathrm{kg}), \mathrm{H}_{\mathrm{v}}=$ heat value of biomass $(\mathrm{kJ} / \mathrm{kg})$, $\mathrm{M}_{\mathrm{w}}=$ mass of moisture removed from maize during drying $(\mathrm{kg})$.

\section{Grain Quality Assessment}

Germination Test

A germination test was conducted after drying to investigating the effect of the dryer on the viability of the dried grains. Grains for the test were sampled from different sections of the dryer and mixed thoroughly and allowed to cool under ambient conditions. For each sample, 100 maize kernels were counted into sterilized seed trays filled with river sand. A litre of water was sprinkled on it and covered with more sand. This was replicated three times for each sample. Emergence count started from the fourth day and continued until there were no visual observations of seedling emergence. The percentage germinated seeds were calculated using Equation 6 as reported by Azadi and Younesi (2013).

$\%$ Germination $=\frac{\text { number of seeds germinated }}{\text { number of seeds in sample }} \times 100$

\section{Stress Crack Test}

Maize grains were randomly sampled from dried grains in the dryer. From the sample, 100 unbroken kernels free from insect attack were counted and analysed for stress cracks. The samples were placed on a light box and checked for single, double, multiple or no cracks. The stress crack index (SCI) for each sample was determined using Equation 7 as proposed by Kirleis and Stroshine (1990).

SCI $=(1 \times$ single crack $)+(3 \times$ double crack $)+(5 \times$ multiple crack $)$

\section{Results and Discussion}

\section{Temperature variation during drying}

Figure 3 shows temperature variations in the plenum of the flatbed dryer compared to the ambient temperature during the drying process. The average temperature observed in the plenum was $55.8^{\circ} \mathrm{C} \pm 1.5^{\circ} \mathrm{C}$ which resulted in a corresponding mean grain surface temperature of $33^{\circ} \mathrm{C} \pm 2.6^{\circ} \mathrm{C}$. The mean temperature in the dryer plenum was twice higher than the mean ambient temperature $\left(26.1^{\circ} \mathrm{C} \pm 0.9^{\circ} \mathrm{C}\right)$ recorded during the same period.

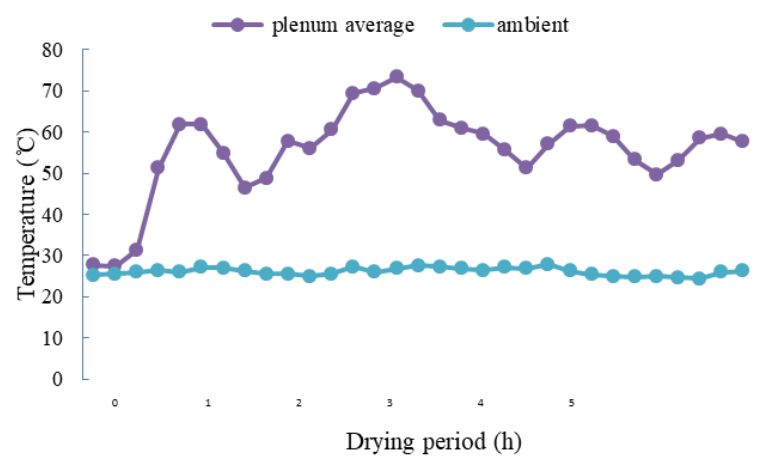

Fig. 3. Temperature variation at plenum and the ambient during the drying experiment.

\section{Variation of moisture content with drying time}

The variation in moisture content in maize grains dried in the flatbed biomass dryer during the drying experiment is shown in Fig. 4. The grain moisture content decreased with drying time with the drying process occurring in the falling rate period, where the moisture content of maize decreased from $18.4 \pm 0.1 \%$ wet basis (w.b.) to $13.3 \pm 0.2 \%$ (w.b.) within a $5 \mathrm{~h}$ period. 


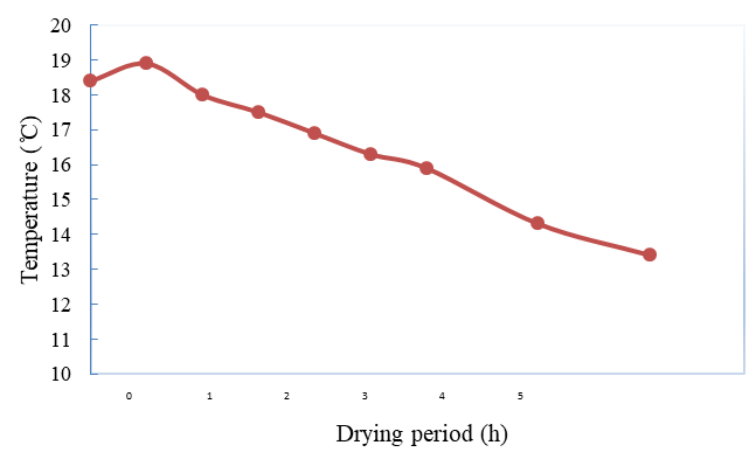

Fig. 4. Moisture content variation with time.

At about 30 minutes from the start of the drying process, it was observed that the average moisture content of grains sampled from the drying bin has increased to $18.9 \pm 0.5 \%$ (wb) as shown in Fig. 5. This occurred because as the drying air moves through the mass of wet maize grains from the plenum, moisture is forced out rapidly from the inner portion of the grains to the surface which settles as surface moisture before evaporation of the moisture occurs. Bitog et al. (2009) reported that when moisture is evaporated from a grain's surface, moisture at the interior part of the grain is diffused to the surface and heat gained by the product must be enough to vaporize the moisture it contains to its surrounding environment until the moisture content of the product comes to equilibrium with the surrounding air. Chakraverty and Singh (2014) also reports this as a common phenomenon in deep bed dryers which leads to grains close to the plenum drying faster compared to grains at top of the drying bin. To address this phenomenon, thorough mixing of grains is recommended for deep bed drying of grains as reported by Kaaya and Kyamuhangire (2010).

\section{Dryer Technical Performance}

The fabricated dryer was used to dry $500 \mathrm{~kg}$ of freshly harvested white maize variety 'Pioneer' during the major maize harvest season in August 2019. Maize grains were dried from an initial moisture content of $18.4 \% \pm 0.1 \%(\mathrm{wb})$ to a final average of moisture content of $13.3 \% \pm 0.2 \%(\mathrm{wb})$ within a drying period of $5 \mathrm{~h}$. At an average drying temperature of $55.8^{\circ} \mathrm{C} \pm 1.5^{\circ} \mathrm{C}$, burner efficiency of $55.4 \%$, and drying efficiency of $67.35 \%$ with specific energy consumption 37 $\mathrm{MJ} / \mathrm{kg}$ moisture removed, an average drying rate of $1.02 \% / \mathrm{h}$ and moisture extraction rate of 6.23 $\mathrm{kg} / \mathrm{h}$ was achieved. The high specific energy consumption recorded could be attributed to the drying temperature decreasing as the drying process progressed with the drying air doing a lot of work to overcome the mass diffusion in the grains internal water and consequent surface moisture evaporation.

\section{Quality parameters}

\section{Stress-crack analysis}

Figure 5 shows the percentage stress crack in dried grains sampled after the drying period. It was revealed that about $7 \%$ of the sampled maize grains had multiple cracks. Both single and double cracks represented $10 \%$ each of the sampled maize grain kernels. Percentage of maize grains with no crack, classified as undamaged grains as shown in Fig. 5 was the highest (78\%). Combination of the level of stress cracks analysed resulted in a stress crack index (SCI) of 75 which infers that the drying temperature did not have an adverse effect on the kernels of the dried maize grains which makes the grains less susceptible to damage or breakage during handling or transportation. The low SCI could be attributed to the low temperature which did not induce internal stresses which could have caused the endosperm becoming pliable (Jony, 2017; Akowuah et al., 2018). Another possible explanation could be the absence of starch gelatinization within the kernels due to the low drying air temperature, which did not induce stress cracks in the endosperm of the grains.

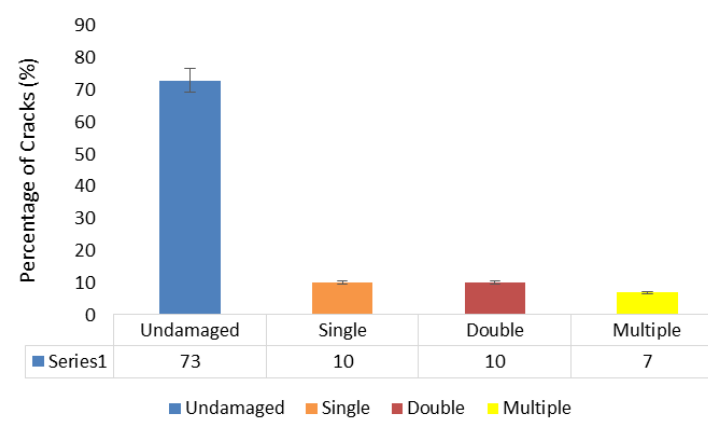

Fig. 5. Percentage of cracks in grains sample.

Effect of drying temperature on germination of dried maize grains

According to the study by Azadi and Younesi (2013), moisture and warm temperature exposure are the principal determinant for seed viability and drying under high temperatures may destroy the seed's viability. The results of this study showed that drying temperature of the flatbed dryer had no substantial effect on the viability of the kernels. The germination count revealed that $90 \%$ of grains sampled from the dryer germinated (Fig. 6). The drying temperatures observed during the study did not lower the germination potential of the dried grains because the seed coat did not undergo adverse stress cracks and the cotyledon were not denatured as reported by Afrakhteh et al. (2013). The germination of maize grains dried in the dryer was within the required 90\% germination rate recommended by the Ghana Certified Seed Producers Association as reported by Akowuah et al. (2018). 


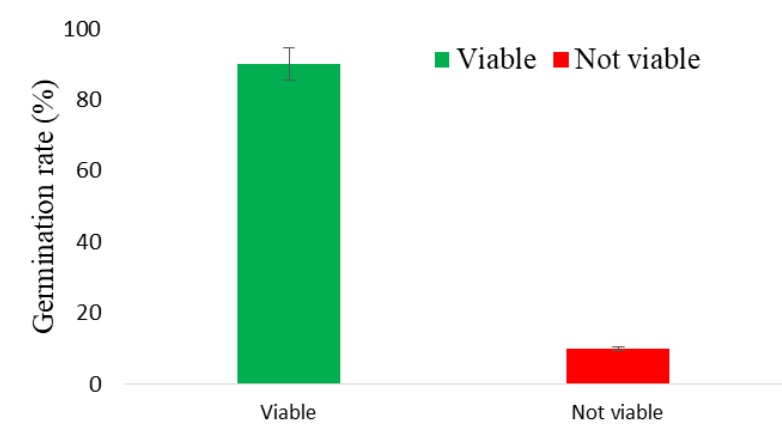

Fig. 6. Percentage sample germinated.

\section{Acknowledgement}

Funding for this study was provided under grants from The Rockefeller Foundation (Grant 2018 FOD 004) and the Foundation for Food and Agriculture Research (Grant DFs-180000000008).

\section{References}

Abass, A.B., Ndunguru, G., Mamiro, P., Alenkhe, B., Mlingi, N. and Bekunda, M. 2014. Postharvest food losses in a maize-based farming system of semi-arid savannah area of Tanzania. J. Stored Prod. Res. 57: 49-57. https://doi.org/10.1016/j.jspr.2013.12.004

Afrakhteh, S., Frahmandfar, E., Hamidi, A. and Ramandi, H.D. 2013. Evaluation of growth characteristics and seedling vigor in two cultivars of soybean dried under different temperature and fluidized bed dryer. Int. $J$. Agric. Crop Sci. 5(21): 2537.

Akowuah, J.O., Maier, D., Opit, G., McNeill, S., Amstrong, P., Campabadal, C. and ObengAkrofi, G. 2018. Drying temperature effect on kernel damage and viability of maize dried in a solar biomass hybrid dryer. Open $J$. Appl. Sci. 8(11): 506-517.

https://doi.org/10.4236/ojapps.2018.811041

Angelucci, F. 2019. Analysis of incentives and disincentives for maize in Ghana. Technical notes series, MAFAP, FAO, Rome. pp. 1-42. https://doi.org/10.21955/gatesopenres.1115958.1

Armah, K.A., Akowuah, J.O., Obeng-Akrofi, G. and McNeill, S.G. 2021. Application of analytic hierarchy process in selection of an appropriate drying platform for maize drying in a solar bubble dryer. Open J. Appl. Sci. 11: 157-175.

https://doi.org/10.4236/ojapps.2021.111011

Azadi, M.S. and Younesi, E. 2013. The effects of storage on germination characteristics and enzyme activity of sorghum seeds. $J$. Stress Physiol. Biochem. 9(4): 289-298.

Bitog, J.P.P., Elauria, J.C., Elepaño, A.R. and Resurreccion, A.N. 2009. Design fabrication and evaluation of a direct-fired corn cob furnace for corn drying. Philippines J. Agric. Biosyst. Eng. 7: 3-15.

Chakraverty, A. and Singh, R.P. 2014. Post-harvest technology and food process engineering. CRC Press. Boca Raton, Florida. pp. 53-57.

Delouche, J.C., Matthes, R.K., Dougherty, G.M. and Boyd, A.H. 2016. Storage of seed in subtropical and tropical regions. Seed Sci. Tech. 1: 671-700.

Jony, A. 2017. Drying and quality features of selected maize varieties dried in commercial processing complexes. Agric. Eng. Int. 19(3): 148-155.

Kaaya, A.N. and Kyamuhangire, W. 2010. Drying maize using biomass-heated natural convection dryer improves grain quality during storage. J. Appl. Sci. 11: 967-974. https://doi.org/10.3923/jas.2010.967.974

Kirleis, A.W. and Stroshine, R.L. 1990. Effects of hardness and drying air temperature on breakage susceptibility and dry milling characteristics of yellow dent corn. Cereal Chem. 67(6): 523-528.

Kumar, D. and Kalita, P. 2017. Reducing postharvest losses during storage of grain crops to strengthen food security in developing countries. Foods. 6(1): 8 . https://doi.org/10.3390/foods6010008

Obeng-Akrofi, G., Akowuah, J.O., Maier, D.E. and Addo, A. 2021. Techno-Economic analysis of a crossflow column dryer for maize drying in Ghana. Agric. 11(6): 568. https://doi.org/10.3390/agriculture11060568

Owusu-Sekyere, E., Obeng-Akrofi, G., Akowuah, J.O. and Maier, D. 2021. Performance analysis and drying kinetics of maize in an AflaSTOP dryer. Open J. Appl. Sci. 11: 327342. https://doi.org/10.4236/ojapps.2021.113024 